\title{
Historic deforestation and the fate of endemic invertebrate species in streams
}

\author{
JON S. HARDING \\ Department of Zoology \\ University of Canterbury \\ Private Bag 4800 \\ Christchurch, New Zealand \\ email: jon.harding@canterbury.ac.nz
}

\begin{abstract}
Deforestation is a global phenomenon threatening the biodiversity of many unique forested ecosystems. The volcanic calderas of Banks Peninsula, New Zealand, experienced widespread deforestation from 1860 to 1900 when $>98 \%$ of the indigenous forest was removed. Streams on the Peninsula possess several regionally-endemic species. The objective of this study was to assess the effect of historic deforestation on stream faunas by surveying the distribution of endemic and other benthic invertebrate species in relation to remnant and regenerating indigenous forest fragments. Twenty-seven sites, in nine catchments were surveyed. Three catchments were dominated by forest, three by farmland, and three were predominantly farmland with forested headwaters. Taxonomic richness was significantly greater in forested streams than agricultural streams, particularly for Ephemeroptera, Plecoptera, and Trichoptera taxa. Distributions of the regionally-endemic hydrobiosid caddisflies Costachorema peninsulae and Edpercivalia banksiensis were restricted to forest fragments. Two other endemics, the stonefly Zelandobius wardi and the caddisfly Hydrobiosis styx, were rarely collected but seemed to be restricted to headwater sites in forest. In contrast, the blepharicerid Neocurupira chiltoni was widely distributed in streams, regardless of land cover, and in relative abundances unrelated to site location within the catchment. Evidence from Banks
\end{abstract}

M02084; Published 20 June 2003

Received 25 October 2002; accepted 16 December 2002
Peninsula streams suggests that throughout New Zealand a number of species unknown to science may have been lost because of past deforestation, and that remnant forested habitats may be vital to the conservation and preservation of regionally endemic species.

Keywords land use; species diversity; stream; endemism; forest fragment; GIS

\section{INTRODUCTION}

Human colonisation of New Zealand c. 900 years B.P. gave rise to an era of widespread deforestation of the land. Before Polynesian and European settlement c. $85 \%$ of the country was covered in indigenous forest, however, by 1997 this had decreased to $23 \%$ (McGlone 1989; Taylor \& Smith 1997). Because of the density of forest, early settlers relied primarily on fire to clear the land. Continual and repeated burning resulted in long-term changes to landscape vegetation, depletion of soil seed banks, and accelerated erosion (Taylor \& Smith 1997). The rate of indigenous forest loss has slowed, and in several regions of New Zealand forest regeneration is occurring.

Early settlers were unaware that their manipulation of the landscape irreversibly altered the fauna of New Zealand. Over the last 900 years, humans have been implicated in the known extinction of $32 \%$ of endemic land and freshwater birds, $18 \%$ of endemic seabirds, and $42 \%$ of our frog species (Taylor \& Smith 1997). In freshwater environments, only one fish species is known to have become extinct (McDowall 1990), however, insufficient records exist to estimate the loss of invertebrate species.

Most of New Zealand's aquatic invertebrate species are endemic (McLellan 1975; Collier 1993). Of the 192 described trichopteran species (Ward pers. comm. 1999) only two are shared with other countries, whereas $90 \%$ of the plecopteran genera (McLellan pers. comm. 1998) are also endemic. 
Collier $(1992,1993)$ in his extensive review of New Zealand aquatic invertebrate literature indicated that over 667 species had been described. Of these species, many have geographically limited distributions. Collier (1992) concluded that 154 species found in surface waters were either regionally isolated or were rarely encountered. Their limited distributions lend support to the view that regions of endemism occur throughout the country (Henderson 1983). Refugia from the late Pleistocene glaciations have been proposed as partial explanations of endemism in Banks Peninsula, Nelson-Marlborough, Otago-Southland, and North Auckland (Craig 1969; Michaelis 1973; Cowley 1978).

Although Banks Peninsula has long been recognised as a region of terrestrial and aquatic endemism (Johns 1986; Wilson 1992), few aquatic studies have focused on species peculiar to the region. The main exception to this is the blepharicerid Neocurupira chiltoni whose distribution was investigated by Craig (1969). More recently, four caddisfly species (Costachorema peninsulae, Edpercivalia banksiensis, Tiphobiosis hinewai, and $T$. childella) and a single stonefly (Zelandobius wardi) have been associated with streams on the Peninsula. A single beetle species (Orchymontia banksiana) is also known to be endemic to the region. It seems likely that other endemic species currently unknown also occur in the region (Johns 1986).

Nationally, the status of many of our regionally endemic aquatic invertebrate species is poorly understood despite widespread threats from expanding human activities. A range of humaninduced threats endanger aquatic species worldwide, including: susceptibility to chemical and organic pollutants entering waterways, habitat loss and degradation because of changing land-use activities, extinctions triggered by the loss of key prey items, the spread of predatory or competitive alien species, and climate change (Allan \& Flecker 1993). On Banks Peninsula, dramatic and swift deforestation occurred over a relatively short period (Petrie 1963). Deforestation undoubtedly caused marked changes to stream morphology and hydrology, and severely degraded in-stream habitats. Although no accounts exist of these effects on stream systems, our understanding of the effect of production forest logging indicates that significant changes would have occurred (Harding et al. 2000).

The aim of this study was to determine whether the diversity of stream invertebrates, particularly regionally endemic species, has been affected by deforestation on Banks Peninsula.

\section{BANKS PENINSULA}

Banks Peninsula lies on the east coast of the South Island between latitudes $43^{\circ} 33^{\prime} \mathrm{S}$ and $43^{\circ} 54^{\prime} \mathrm{S}$, and comprises a doublet of extinct calderas formed by the Lyttleton and Akaroa volcanoes (Porteous 1987). The Lyttleton and Akaroa volcanoes were formed 23 million years ago, and remained isolated from the South Island until the formation of the Canterbury Plains (Stevens 1980). The Canterbury Plains are a climatically and geomorphologically distinct region of flat, intensively farmed alluvial gravels adjoining the western boundary of the Peninsula (Harding \& Winterbourn 1997). The Peninsula rises to c. $1000 \mathrm{~m}$ a.s.l., and is dissected by $>100$ isolated, short, steep stream catchments.

Before widespread European settlement in the 1840 s, much of the Peninsula was covered in totaradominated podocarp forest (Norton \& Fuller 1994). In lowland areas $(<300 \mathrm{~m}$ a.s.l.) mixtures of totara (Podocarpus totara), matai (Podocarpus spicatus), and kahikatea (Podocarpus dacrydioides) forest occurred, whereas at the higher elevations mountain totara (Podocarpus hallii) and mountain cedar (Libocedrus bidwilli) were abundant. Limited pockets of beech forest (Nothofagus spp.) occurred along the upper ridges and valleys of a few southern bays (Petrie 1963). From 1840 to 1860 , very little forest (c. 1800 ha) was felled (Petrie 1963). However from 1860 to the 1880s, logging intensified as a result of the replacement of pit-sawing with stream-driven sawmills. During this period much of the indigenous forest was removed from the central, southern, and western areas of the Peninsula. From 1864 to 1868, 1.5 million cubic feet of timber was cut in mills near Akaroa, the largest township on the Peninsula (Porteous 1987). By 1900, only 61 ha of the 56600 ha of podocarp forest estimated to be present in 1840 remained (Porteous 1987) (Fig. 1). Today, most of the land above $300 \mathrm{~m}$ a.s.1. is dominated by tussock, whereas many of the valley floors have been converted to pasture, primarily cocksfoot and ryegrasses grazed by sheep and beef cattle. Pockets of scrub including gorse (Ulex europaeus), Monterey pine (Pinus radiata), stinging nettle (Urtica spp.), and mixed podocarp species occur along riparian zones of many smaller streams throughout the Peninsula. Isolated fragments of old growth and regenerating podocarp forest are found in a few valleys, scenic reserves, and in the steeper headwaters of some streams. 

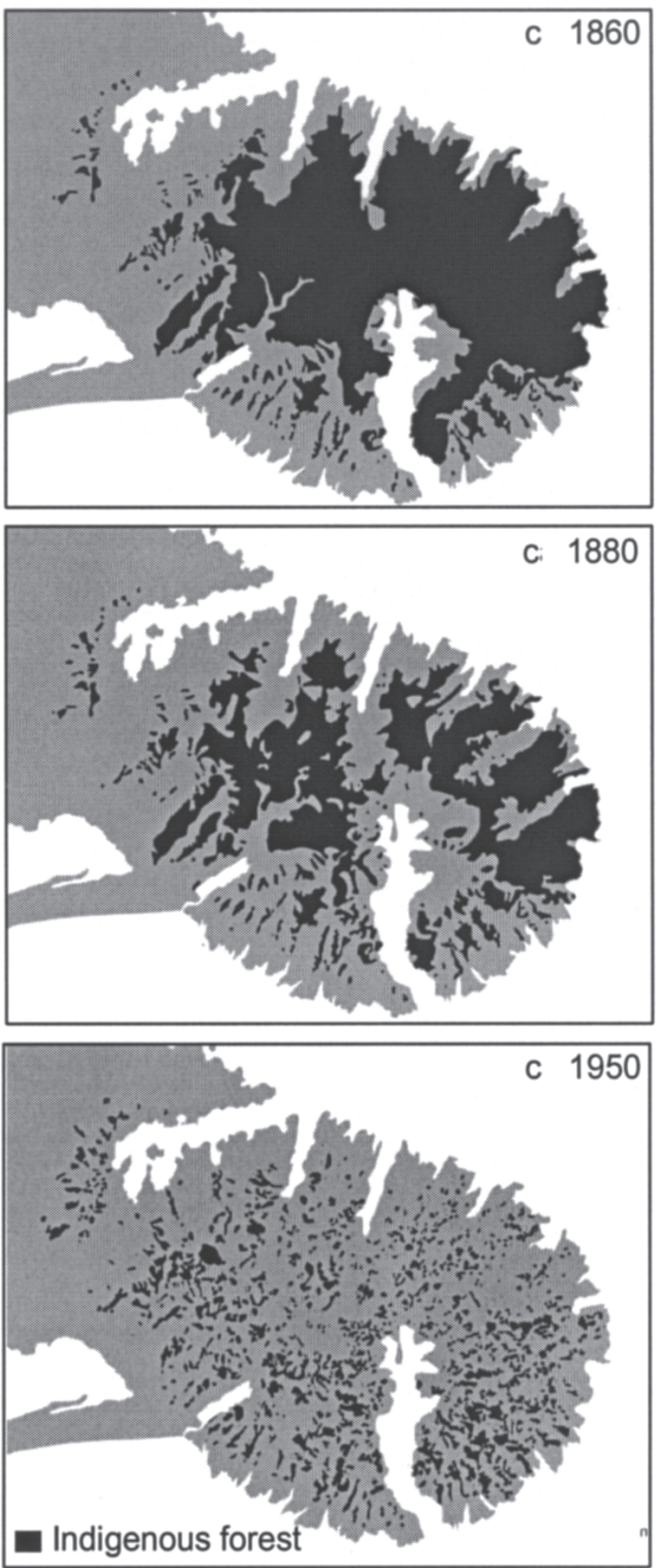

Fig. 1 Estimated indigenous forest cover for Banks Peninsula, New Zealand in the 1860s, 1880s, and 1950s (modified from Petrie 1963).

\section{METHODS}

Nine river catchments were selected for the study (Fig. 2). Three had indigenous forest predominating in their riparian zones, three were mixed land-use catchments with headwater riparian zones dominated by forest but with mid and lower reaches in agriculture, and three were predominantly agricultural. Within each catchment three sites were sampled, a headwater, mid catchment, and lower stream site (Table 1).

Land cover in each catchment was assessed from the NZTopo digital database (Land Information New Zealand 2000) using GIS (ArcView 3.2, Environmental Systems Research 1999). The percentage of indigenous forest, scrub, and pasture within $100 \mathrm{~m}$ of each stream was estimated above each site to the catchment source. These riparian data collected from NZTopo were verified by image analysis of 1:27 000 aerial photos.

All sites were sampled twice- once in each of the summers of 1998 and 1999. Mean stream width, depth, and current velocity were measured at each site by calculating values from transects at three locations. Conductivity (at $25^{\circ} \mathrm{C}$ ), dissolved oxygen, and temperature measurements were made with a YSI 85 field meter, and $\mathrm{pH}$ with an Orion model 210A meter.

At each site, invertebrates were collected by kicknet sampling ( $0.5 \mathrm{~mm}$ mesh) from throughout a $10 \mathrm{~m}$ reach. Riffle, run, and pool habitats were sampled including stream margins, submerged root masses, woody debris, and large boulders. Samples were preserved in the field in a $5 \%$ formalin- $10 \%$ ethanol mix, and sorted and identified in the laboratory under $10 \times$ magnification. Invertebrates were identified to the lowest taxonomic level possible except for chironomids that were identified to genus and oligochaetes to family. For the purpose of analysis "endemic" species were assumed to include described and undescribed species believed to be locally endemic. The larva of several species are known but not formally described (e.g., C. peninsulae, E. banksiensis, and Z. wardi), these identifications were confirmed from a mixture of Canterbury Museum specimens, pupal cocoons, and adult associations.

Several diversity indices including taxonomic richness, number of Ephemeroptera, Plecoptera, and Trichoptera taxa (EPT taxa) and Margalef's Index were calculated by combining data from both sampling periods. Margalef's Index accounts for both taxonomic richness and total abundance of 


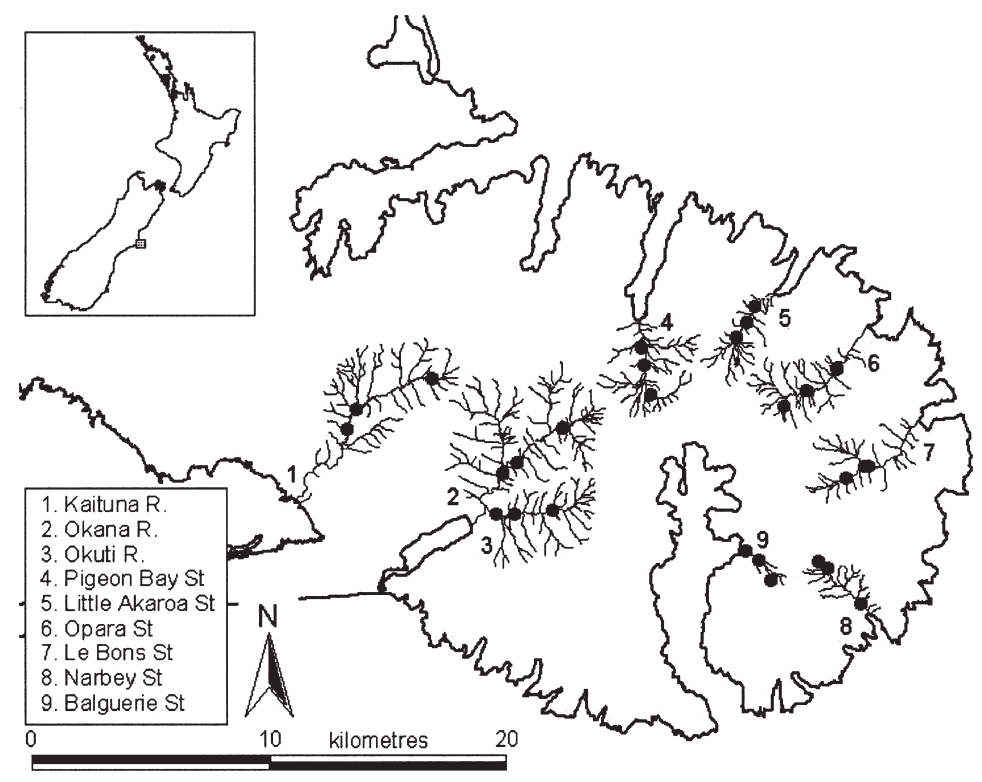

Fig. 2 Map of the nine study catchments on Banks Peninsula, New Zealand with 27 sites sampled in the summers of 1998 and 1999.

Table 1 Dominant riparian vegetation and geographical characteristics (mean \pm SE) of the site groups $(n=3$ streams per group). (F, forest; M, mixed; A, agriculture; H, headwater; M, mid site; L, lower site.)

\begin{tabular}{lllccc}
\hline Land use type & Code & $\begin{array}{l}\text { Riparian } \\
\text { vegetation }\end{array}$ & Stream order & Elevation (m) & $\begin{array}{c}\text { Distance from } \\
\text { headwaters }(\mathrm{km})\end{array}$ \\
\hline $\begin{array}{l}\text { Forest } \\
\text { Headwater sites }\end{array}$ & FH & Forest & $1.6 \pm 0.3$ & $280 \pm 53$ & $1.3 \pm 0.5$ \\
$\begin{array}{l}\text { Mid sites } \\
\text { Lower sites }\end{array}$ & FM & Forest & $2.0 \pm 0$ & $146 \pm 44$ & $2.4 \pm 0.6$ \\
$\begin{array}{l}\text { Mixed } \\
\text { Headwater sites }\end{array}$ & MH & Forest & $2.6 \pm 0.3$ & $33 \pm 9$ & $3.5 \pm 0.5$ \\
$\begin{array}{l}\text { Mid sites } \\
\text { Lower sites }\end{array}$ & FM & Forest & $2.6 \pm 0.3$ & $170 \pm 38$ & $2.7 \pm 0.3$ \\
$\begin{array}{l}\text { Agriculture } \\
\text { Headwater sites }\end{array}$ & PL & Pasture & $3.0 \pm 0$ & $50 \pm 17$ & $5.5 \pm 0.8$ \\
$\begin{array}{l}\text { Mid sites } \\
\text { Lower sites }\end{array}$ & AM & Pasture & $3.3 \pm 0.3$ & $18 \pm 2$ & $6.6 \pm 0.9$ \\
\hline
\end{tabular}

organisms (Magurran 1988). Comparisons of physico-chemical, species richness, diversity indices, and community data among land use types and stream size were made on untransformed data with nested ANOVA (SYSTAT 10, SPSS 2000). Significance between treatments was identified by Tukey HSD multiple comparisons and was accepted at $P<0.05$. Invertebrate communities at each site were compared by Detrended Correspondence Analysis (DCA) using presence-absence data (McCune \& Mefford 1999).

\section{RESULTS}

Land cover analysis confirmed that sites in "forested" catchments (FH, FM, and FL) had 100 m riparian zones generally dominated by indigenous forest, however, several sites (e.g., Balgueri Stream) had significant amounts of regenerating scrub in their riparian zones (Fig. 3). In mixed catchments, the $100 \mathrm{~m}$ riparian zones of headwater sites were dominated by forest $(\mathrm{MH})$, and the mid and lower reaches by pasture (MM, ML), whereas all sites in 


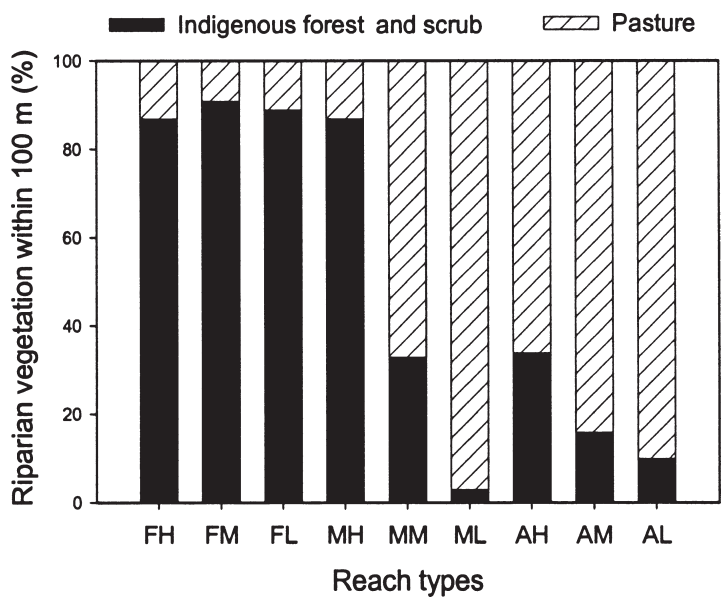

Fig. 3 Average riparian cover within $100 \mathrm{~m}$ of streams above nine stream reach types $(\mathrm{F}$, forest; $\mathrm{M}$, mixed; $\mathrm{A}$, agriculture; $\mathrm{H}$, headwater; $\mathrm{M}$, mid site; $\mathrm{L}$, lower site).

the agricultural catchments (AH, AM, and AL) had riparian zones dominated by pasture (Fig. 3).

In general, streams had circum-neutral $\mathrm{pH}$ ranging from 7.4 to 8.1 , were well oxygenated (68$109 \%$ ), and had conductivities ranging from 70 to $152 \pm \mu \mathrm{S} \mathrm{cm}^{-1}$. Significant differences in several physico-chemical parameters were detected between sites in different land use. Forested streams were narrower than agricultural streams, and had significantly lower spot temperatures and conductivities (Table 2). Site location in the catchment resulted in significant differences in depth (Table 2).

A total of 68 benthic invertebrate taxa were collected from the nine catchments (Appendix 1). Most taxa (32) were recorded from a forested headwater site (Kaituna River) and fewest (14) from an agricultural lower reach site (Opuahou Stream). Total taxonomic richness was significantly higher in forested than agricultural streams, regardless of site location within the catchment (Table 3, Fig. 4). Similarly, significantly higher values were found at forested sites for Margalef's Index, and the number of EPT taxa (Table 3). Agricultural sites downstream from forested headwaters (MM sites) had consistently higher taxonomic richness, Margalef's Index, and numbers of EPT taxa than other agricultural sites (Fig. 3). Low numbers of endemic species (ranging from 0 to 6) were recorded at all sites and vegetation had no significant effect on endemic richness (Table 3, Fig. 4). Higher numbers of endemic species were generally found at

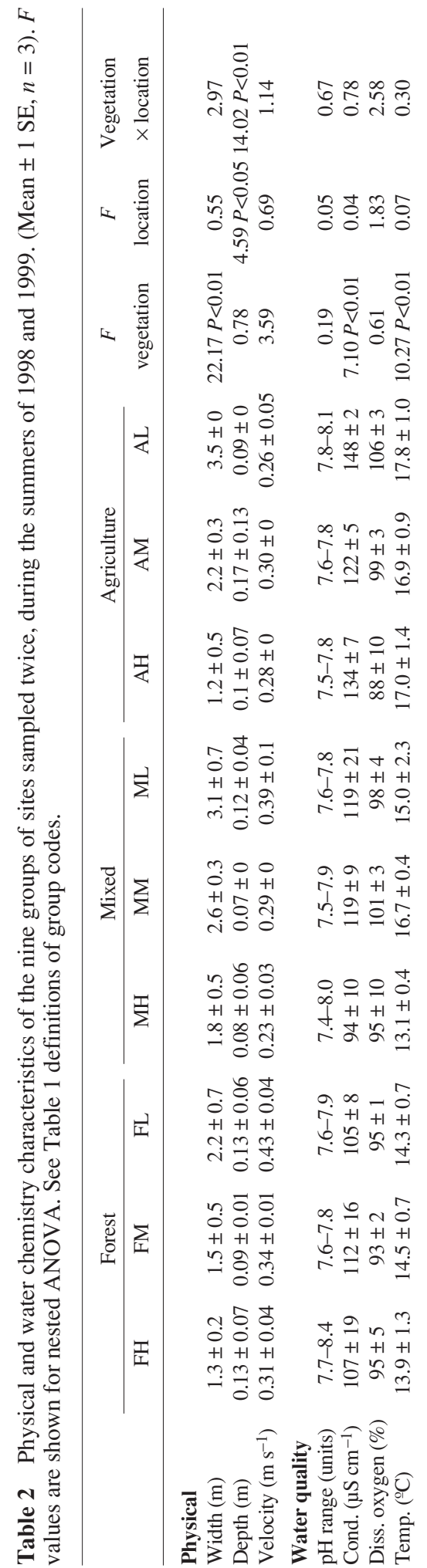


headwater sites. Analysis of the composition of each of the 27 invertebrate communities showed that forested sites were dominated by Ephemeroptera, which accounted for $40-50 \%$ of the fauna, whereas Plecoptera, though never abundant, were present at forested sites but rarely at agricultural sites. In contrast, agricultural sites were dominated by dipterans, molluscs, and oligochaetes (Fig. 4). DCA generally clustered forested sites, regardless of location within the catchment, towards the right hand end of Axis 1, whereas agricultural sites clustered to the left (Fig. 5). A single forested site in the headwaters of Balgueri Stream clustered among the agricultural sites; it also had the lowest taxonomic richness and lowest percentage of forest cover (high scrub) of any forested site.

The distribution of several endemic species was strongly influenced by vegetation (Fig. 6). The hydrobiosid caddisflies $C$. peninsulae and $E$. banksiensis were collected at forested sites, but were absent from all sites on agricultural streams (Fig. 6). Two other endemics, the stonefly $Z$. wardi and the caddisfly Hydrobiosis styx, were rarely collected, and were found only at headwater forested sites and one mid-catchment forested site (Z. wardi) (Fig. 6). In contrast, the blepharicerid Neocurupira chiltoni was found in all catchments, regardless of vegetation, and in relative abundances unrelated to site location within the catchment (Fig. 6).

\section{DISCUSSION}

Over the past 1000 years much of New Zealand has experienced widespread deforestation, and subsequent modification of vegetation and land use. The effects of present-day agricultural activities on stream morphology, water quality (particularly nutrients, temperature, and turbidity), and bank stability have been documented widely (Harding et al. 1999; Quinn \& Stroud 2002). Furthermore, numerous studies have focused on the effects of land use on invertebrate communities (Harding \& Winterbourn 1995; Quinn et al. 1997; Townsend et al. 1997; Hall et al. 2001). In contrast, the effects of historic deforestation, and the conversion of

Table 3 Nested ANOVAs for invertebrate indices in relation to vegetation (forest, mixed, and agriculture), the position of each site within the river (headwater, mid reach and lower reach), and the river catchment being sampled (river). Values in bold are significant.

\begin{tabular}{lrrrc}
\hline Source & d.f. & MS & $F$ ratio & $P$ \\
\hline Taxa & & & & \\
Vegetation & 2 & 210.704 & 39.24 & $\mathbf{0 . 0 0 1}$ \\
River (vegetation) & 2 & 5.370 & 0.302 & 0.911 \\
Position & 4 & 37.926 & 2.301 & 0.143 \\
Position*vegetation & 6 & 28.093 & 1.704 & 0.213 \\
Error & 12 & 16.489 & & \\
EPT taxa & & & & \\
Vegetation & 2 & 14.33 & 2.52 & $\mathbf{0 . 0 0 1}$ \\
River (vegetation) & 2 & 2.630 & 0.463 & 0.823 \\
Position & 4 & 75.444 & 13.270 & 0.122 \\
Position*vegetation & 6 & 13.778 & 2.423 & 0.105 \\
Error & 12 & 5.685 & & \\
Margalef's Index & & & & \\
Vegetation & 2 & 8.272 & 39.46 & $\mathbf{0 . 0 0 0}$ \\
River (vegetation) & 2 & 0.207 & 0.382 & 0.876 \\
Position & 4 & 0.990 & 1.833 & 0.202 \\
Position*vegetation & 6 & 0.836 & 1.549 & 0.250 \\
Error & 12 & 0.540 & & \\
Endemic species & & & & \\
Vegetation & 2 & 3.370 & 6.06 & 0.095 \\
River (vegetation) & 2 & 0.556 & 0.476 & 0.814 \\
Position & 4 & 3.815 & 3.270 & 0.074 \\
Position*vegetation & 6 & 2.259 & 1.937 & 0.169 \\
Error & 12 & 1.167 & & \\
\hline
\end{tabular}



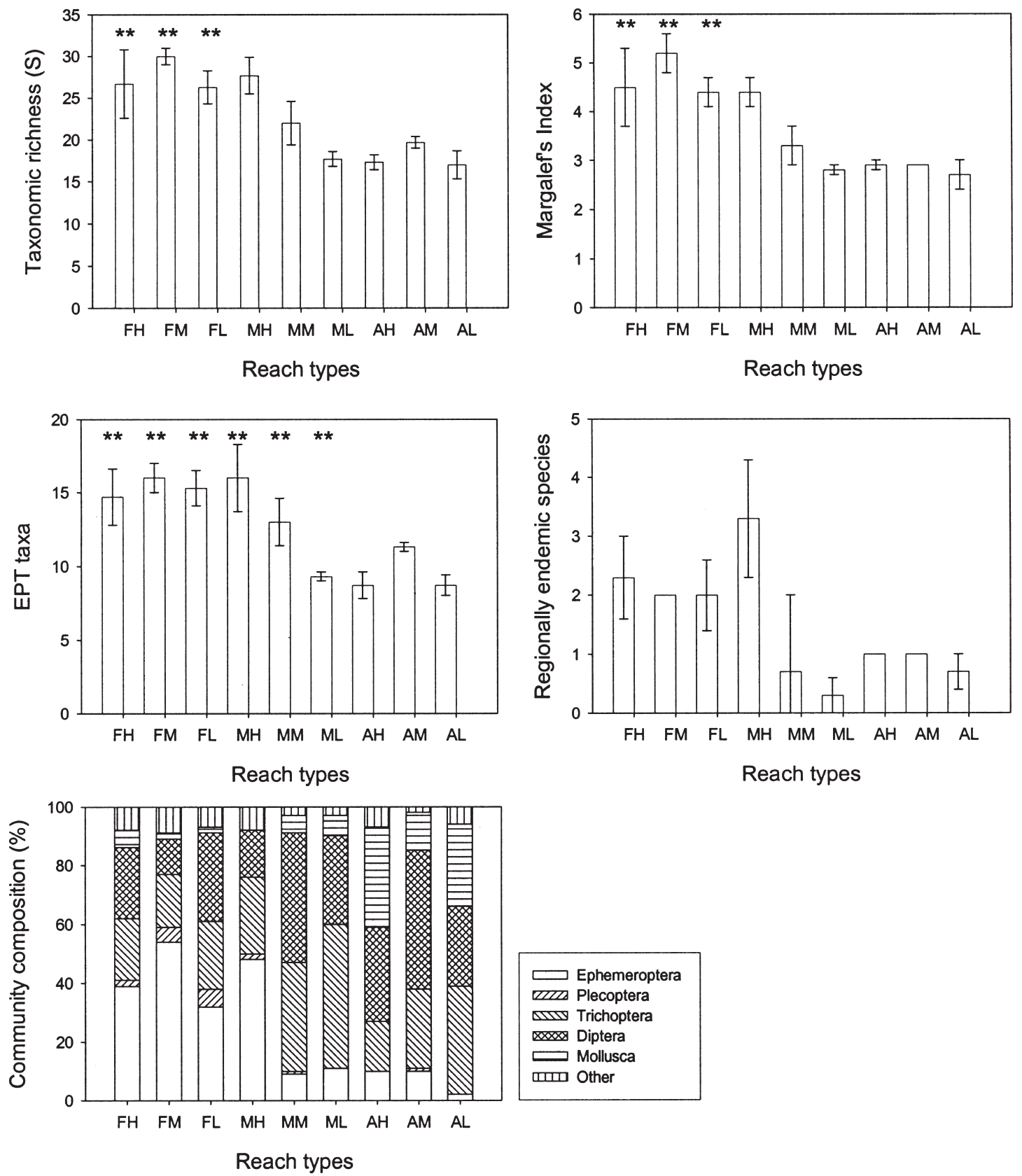

Fig. 4 Invertebrate taxonomic richness and community composition values for combined 1998 and 1999 data for forested (open bars) and agricultural (shaded bars) headwater (H), mid site (M), and lower site (L). Values are means $\pm 1 \mathrm{SE}, n=3$, whereas significant differences are shown from Tukey HSD multiple comparisons. (EPT, Ephemeroptera, Trichoptera, and Ephemeroptera taxa.) 


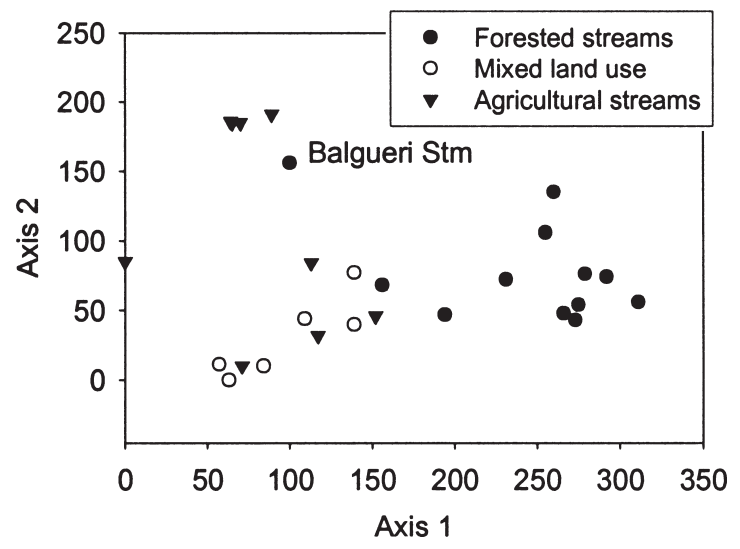

Fig. 5 Detrended Correspondence Analysis of benthic invertebrate communities at 27 sites on nine Banks Peninsula, New Zealand, streams for combined 1998 and 1999 data. (Closed circles indicate forested streams, open circles mixed land-use streams, and closed triangles agricultural streams.)

indigenous forest to farmland, as on Banks Peninsula, are poorly documented. Findings in this study, of significantly higher taxonomic richness, Margalef's Index, and EPT taxa values at forested rather than agricultural sites, are consistent with results reported for other sites throughout the South Island (Harding et al. 1997; Hall et al. 2001), although investigations in North Island hill-country streams have failed to detect effects on taxonomic richness and EPT richness (Quinn et al. 1997; Scarsbrook \& Halliday 1999). Studies on the impacts of logging have indicated that in the short term, deforestation can result in significant changes to stream channel morphology, flow, sedimentation, and in-stream habitat for invertebrates and fish (Morgan \& Graynoth 1978; Graynoth 1979; Wallace et al. 1988; Harding et al. 2000), and might be expected to result in severe stresses on endemic species adapted to relatively stable, low sediment, forest habitats. Thus, Stone \& Wallace (1998) found that 16 years after logging and replanting, benthic invertebrate abundance, biomass, and EPT abundance had still not recovered to pre-logging levels in a North Carolina stream, whereas Harding et al. (1998) showed that the effects on species diversity of logging and subsequent long-term agriculture can persist for many decades. The only New Zealand freshwater species known to have become extinct because of human activities is the Southern grayling (Prototroctes oxyrhynchus) (McDowall 1990). The decline in numbers of this fish was observed between
1860 and 1900 (McDowall 1990), and anecdotal evidence implicated the removal of forest in conjunction with conversion to farmland as significant causal factors in its extinction (McDowall 1990). The results of this study indicate that several species found only on Banks Peninsula have distributions restricted to indigenous forest fragments. By implication, removal of these forest remnants would result in their extinction. Diamond (1984) in his study of New Zealand native bird distributions suggested that logging and forest fragmentation on Banks Peninsula has resulted in the extinction of at least 12 bird species from the region.

The presence of H. styx at a number of sites is of particular interest; this species was originally described from specimens collected in the Styx River, near Christchurch in 1951. Despite repeated sampling by the author and others, H. styx has not been found in the Styx River again or in any other Christchurch stream since then. The Styx River is considered one of the least impacted of Christchurch's rivers, however its current condition differs substantially from the spring-fed stream in indigenous forest occurring before European settlement. It is possible that $H$. styx and other species not recently recorded on the plains (e.g., Harding 1994) may have been widely distributed within the forested lowlands before forest removal. Its current distribution would seem to be restricted to forested headwater streams on Banks Peninsula.

In contrast to $H$. sty $x$, the blepharicerid $N$. chiltoni is widely distributed on the Peninsula (Craig 1969). Blepharicerids typically are found in torrential, well oxygenated, mountain streams. The relatively extensive distribution of $N$. chiltoni in Banks Peninsula streams may be partially a result of the steep, boulder dominated, and well oxygenated nature of these streams, whose relatively short lengths ensure that water temperatures remain relatively cool in summer even in agricultural catchments. Under these circumstances the removal of forest may have enhanced the habitat of this algalgrazing species by enabling greater algal growth in weakly-shaded agricultural streams.

Without a better understanding of the ecological requirements of these endemic species it is difficult to speculate on the causal mechanisms that limit their current distributions. However, multivariate analysis (Fig. 5) revealed that the forested headwater site on Balgueri Stream had a community more similar to those at agricultural sites than forested ones. The riparian zone in this reach of Balgueri Stream was 
A, Costachorema peninsulae FOREST MIXED
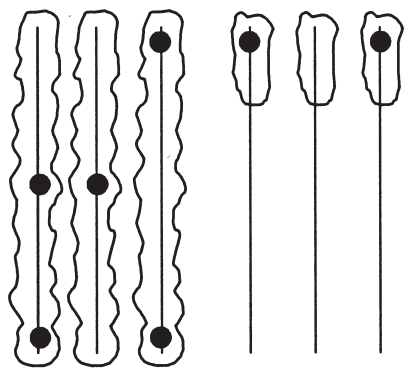

AGRICULTURE

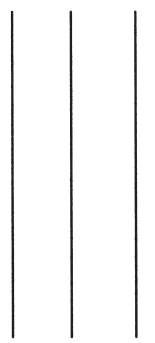

\section{C, Zelandobius wardi} FOREST

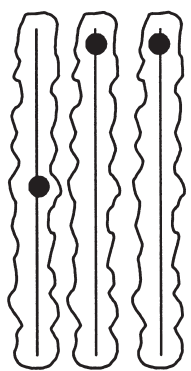

MIXED

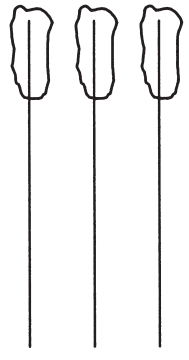

AGRICULTURE

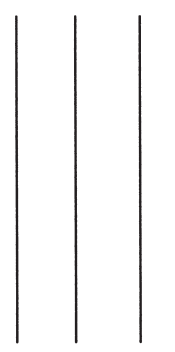

\section{E, Neocurupira chiltoni}

FOREST

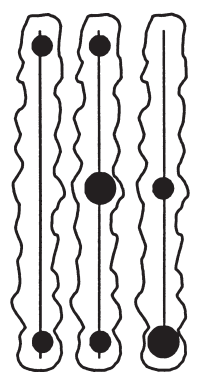

MIXED

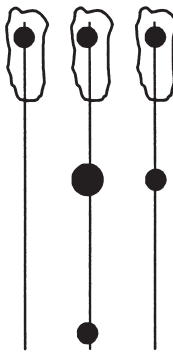

AGRICULTURE

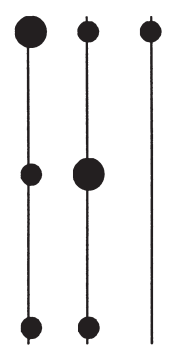

$\mathrm{B}$, Edpercivalia banksiensis FOREST

MIXED AGRICULTURE
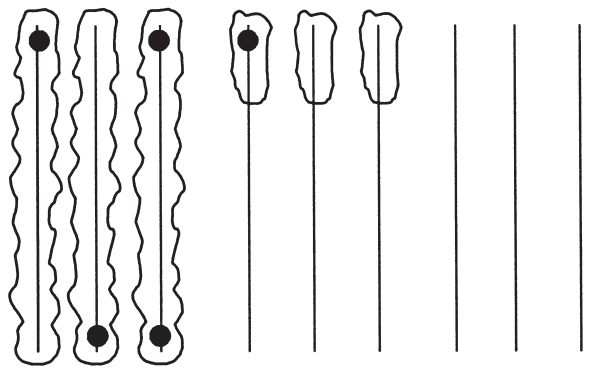

D, Hydrobiosis styx FOREST MIXED AGRICULTURE
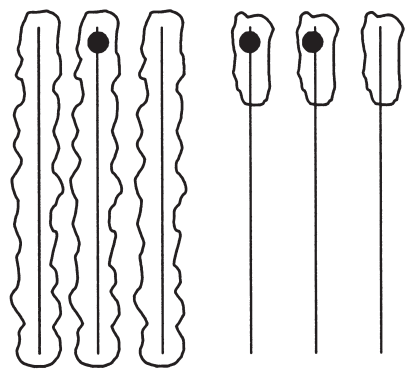

Fig. 6 Presence (and relative abundance for Neocurupira chiltoni) of key endemic species at 27 headwater, mid site, and lower sites in nine river systems. Size of the circle indicates comparative abundance.

This study is one of the few in New Zealand that has documented the likely impact of deforestation and conversion to agriculture on the diversity of endemic benthic invertebrates. It is impossible to estimate how many endemic species have already become extinct during the past 900 years of human settlement in New Zealand. However, lessons from Banks Peninsula streams provide a warning that species unknown to science have probably been lost, and that remnant forested habitats are likely to be vital for the conservation and preservation of regionally endemic species. 


\section{ACKNOWLEDGMENTS}

Malcolm Main and Adrian Meredith of Environment Canterbury generously provided 1:27000 aerial photographs and useful discussion. Thanks to Sinnet Frisk and Robert Ewers for producing the GIS maps of Banks Peninsula and Hugh Wilson of the Maurice White Native Forest Reserve Trust for kindly allowing me to sample in Hinewai Reserve. Thanks to Mike Winterbourn for his comments and improvements on a draft of this manuscript, Angus McIntosh for statistical advice, and John Ward for access to Canterbury Museum specimens and information on caddisfly distribution. Two anonymous referees also provided useful additional comments.

\section{REFERENCES}

Allan, J. D.; Flecker, A. S. 1993: Biodiversity conservation in running waters. Bioscience 43: 32-43.

Collier, K. J. 1992: Freshwater macroinvertebrates of potential conservation interest. Science \& Research Series No. 50. Wellington, Department of Conservation.

Collier, K. J. 1993: Review of the status, distribution, and conservation of freshwater invertebrates in New Zealand. New Zealand Journal of Marine and Freshwater Research 27: 339-356.

Cowley, D. R. 1978: Studies on the larvae of New Zealand Trichoptera. New Zealand Journal of Zoology 5: 639-750.

Craig, D. A. 1969: A taxonomic revision of New Zealand Blepharoceridae and the origin and evolution of the Australian Blepharoceridae (Diptera: Nematocera). Transactions of the Royal Society of New Zealand, Biological Sciences 11: 101-151.

Diamond, J. M. 1984: Distributions of New Zealand birds on real and virtual islands. New Zealand Journal of Ecology 7: 37-55.

Environmental Systems Research 1999: ArcView 3.2.

Graynoth, E. 1979: Effects of logging on stream environments and faunas in Nelson. New Zealand Journal of Marine and Freshwater Research 13: 79-109.

Hall, M. J.; Closs, G. P.; Riley, R. H. 2001: Relationships between land use and stream invertebrate community structure in a South Island, New Zealand, coastal stream catchment. New Zealand Journal of Marine and Freshwater Research 35: 591-603.

Harding, J. S. 1994: Lotic ecoregions of New Zealand. Unpublished $\mathrm{PhD}$ thesis, University of Canterbury, Christchurch, New Zealand. 191 p.
Harding, J. S.; Winterbourn, M. J. 1995: Effects of contrasting land use on physico-chemical conditions and benthic assemblages of streams in a Canterbury (South Island, New Zealand) river system. New Zealand Journal of Marine and Freshwater Research 29: 479-492.

Harding, J. S.; Winterbourn, M. J. 1997: An ecoregion classification of the South Island, New Zealand. Journal of Environmental Management 51: 275287.

Harding, J. S.; Winterbourn, M. J.; McDiffett, W. F. 1997: Stream faunas and ecoregions in South Island, New Zealand: do they correspond? Archiv für Hydrobiologie 140: 289-307.

Harding, J. S.; Benfield, E. F.; Bolstad, P. V.; Helfman, G. S.; Jones E. B. D. 1998: Stream biodiversity: the ghost of land-use past. Proceedings of the National Academy of Sciences 95: 14843-14847.

Harding, J. S.; Young, R. G.; Hayes, J. W.; Shearer, K. A.; Stark, J. D. 1999: Changes in agricultural intensity and river health along a river continuum. Freshwater Biology 42: 345-357.

Harding, J. S.; Quinn, J.; Hickey, C. 2000: Effects of mining and production forestry. In: Collier, K. J.; Winterbourn, M. J. ed. New Zealand stream invertebrates: ecology and implications for management. Christchurch, New Zealand Limnological Society. Pp. 230-259.

Henderson, I. M. 1983: A contribution to the systematics of New Zealand Philopotamidae (Trichoptera). New Zealand Journal of Zoology 10: 163-176.

Johns, P. M. 1986: Arthropods of Banks Peninsula Reserves. Report to the Commissioner of Crown Lands, New Zealand. 114 p.

Land Information New Zealand 2000: NZTopo digital database. Wellington, New Zealand.

McCune, B.; Mefford, M. J. 1999: Multivariate analysis of ecological data. Version 4.01, MjM Software, Gleneden Beach, Oregon, United States.

McDowall, R. M. 1990: New Zealand freshwater fishes: a natural history and guide. Wellington, New Zealand, Heinemann Reed-MAF Publishing Group.

McGlone, M. S. 1989: The Polynesian settlement of New Zealand in relation to environmental and biotic changes. New Zealand Journal of Ecology 12: 115-130.

McLellan, I. D. 1975: The freshwater insects. In: Kuschel, G. ed. Biogeography and ecology in New Zealand. The Hague, Junk. Pp. 537-559.

Magurran, A. E. 1988: Ecological diversity and its measurement. Princetown, Princetown University Press. 179 p. 
Michaelis, F. B. 1973: The distribution and life history of Rakiura vernale (Trichoptera: Helicopsychidae). Journal of the Royal Society of New Zealand 3: 295-304.

Morgan, D. R.; Graynoth, E. 1978: The influence of forestry practices on the ecology of freshwater fish in New Zealand. Fisheries Research Division Occasional Publication No. 14. Wellington, New Zealand. $36 \mathrm{p}$.

Norton, D. A.; Fuller, P. F. 1994: Restoration of lowland forest in Canterbury. New Zealand Forestry 39: 21-22.

Petrie, L. M. 1963: From bush to cocksfoot: an essay on the destruction of Bank's Peninsula's forest. Unpublished MSc thesis, Department of Geography, University of Canterbury, Christchurch, New Zealand.

Porteous, T. 1987: The Banks Peninsula landscape. Wellington, Queen Elizabeth II National Trust (NZ). $31 \mathrm{p}$.

Quinn, J. M.; Stroud, M. J. 2002: Water quality and sediment and nutrient export from New Zealand hill-land catchments of contrasting land use. New Zealand Journal of Marine and Freshwater Research 36: 409-430.

Quinn, J. M.; Cooper, A. B.; Davies-Colley, R. J.; Rutherford, J. C.; Williamson, R. B. 1997: Land use effects on habitat, water quality, periphyton, and benthic invertebrates in Waikato, New Zealand hill-country streams. New Zealand Journal of Marine and Freshwater Research 31: 579-597.
Scarsbrook, M. R.; Halliday, J. 1999: Transition from pasture to native forest land-use along stream continua: effects on stream ecosystems and implications for restoration. New Zealand Journal of Marine and Freshwater Research 33: 293310.

Stevens, G. R. 1980: New Zealand adrift. Wellington, A. H. \& A. W. Reed. 442 p.

Stone, M. K.; Wallace, J. B. 1998: Long-term recovery of a mountain stream from clear-cut logging: the effects of forest succession on benthic invertebrate community structure. Freshwater Biology 39: 151-169.

Taylor, R.; Smith, I. 1997: The state of New Zealand's environment. Wellington, Ministry for the Environment.

Townsend, C. R.; Arbuckle, C. J.; Crowl, T. A.; Scarsbrook, M. R. 1997: The relationship between land use and physicochemistry, food resources and macroinvertebrate communities in tributaries of the Taieri River, New Zealand: a hierarchically scaled approach. Freshwater Biology 37: 177191.

Wallace, J. B.; Gurtz, M. E.; Smith-Cuffney, F. 1988: Long-term comparisons of insect abundances in disturbed and undisturbed Appalachian headwater streams. Verhandlungen der Internationale Vereinigung für theoretische und angewandte Limnologie 23: 1224-1231.

Wilson, H. D. 1992: Banks ecological region: Port Hills, Herbert and Akaroa ecological districts. Protected Natural Areas Program Survey Report 21. New Zealand, Department of Conservation. 347 p. 
Appendix 1 Taxa present at nine groups of sites sampled in summer 1998 and 1999. (F, forest; M, mixed; A, agriculture; $\mathrm{H}$, headwater; $\mathrm{M}$, mid site; L, lower site.)

\begin{tabular}{|c|c|c|c|c|c|c|c|c|c|}
\hline & $\mathrm{FH}$ & $\mathrm{FM}$ & FL & $\mathrm{MH}$ & MM & ML & $\mathrm{AH}$ & $\mathrm{AM}$ & $\mathrm{AL}$ \\
\hline \multicolumn{10}{|l|}{ EPHEMEROPTERA } \\
\hline Austroclima jollyae & + & + & + & + & + & & & + & \\
\hline Coloburiscus humeralis & + & + & + & + & + & + & + & + & \\
\hline Deleatidium spp. & + & + & + & + & + & + & + & + & + \\
\hline Nesameletus ornatus & + & & & & & & & & \\
\hline Nesameletus sp. A & + & + & + & + & & & & & \\
\hline Zephlebia spp. & + & + & + & + & & & & & \\
\hline \multicolumn{10}{|l|}{ PLECOPTERA } \\
\hline Acroperla spiniger & & & & & & & + & & \\
\hline Acroperla trivacuata & + & + & & + & + & & & & \\
\hline Austroperla cyrene & + & + & + & + & & & & & \\
\hline Zelandoperla decorata & + & + & + & + & + & & & + & \\
\hline Zelandoperla spp. & & + & + & & & & & & \\
\hline Zelandobius wardi & + & + & & & & & & & \\
\hline Spaniocercoides sp. & & + & & & & & & & \\
\hline \multirow{2}{*}{\multicolumn{10}{|c|}{ MEGALOPTERA }} \\
\hline & & & & & & & & & \\
\hline $\begin{array}{l}\text { Archichauliodes diversus } \\
\text { COLEOPTERA }\end{array}$ & \multicolumn{3}{|c|}{ COLEOPTERA } & + & + & + & & + & + \\
\hline Elmidae & + & + & + & + & + & & + & + & \\
\hline Hydrophilidae & & + & + & & & & & & \\
\hline Ptilodactylidae & & + & & + & & & & & \\
\hline Scirtidae & + & + & + & + & & & & & \\
\hline \multicolumn{10}{|l|}{ DIPTERA } \\
\hline Aphrophila neozelandica & + & + & + & + & & & & + & \\
\hline Austrosimulium spp. & + & + & + & + & + & + & + & + & + \\
\hline Empididae & + & + & + & + & & & & & \\
\hline Limonia sp. & + & & & & & & & & \\
\hline Maoridiamesa & + & + & + & + & + & + & + & + & + \\
\hline Neocurupira chiltoni & + & + & + & + & + & + & + & + & + \\
\hline Nothodixa sp. & + & + & + & & + & & + & & \\
\hline Orthocladiinae & + & + & + & + & + & + & + & + & + \\
\hline Psychodidae & & + & + & & & & & & \\
\hline Tanyderidae & + & + & + & + & & + & & & \\
\hline Tanypodinae & + & + & + & + & + & + & + & & + \\
\hline Tipulidae & + & + & & + & & & & & \\
\hline \multicolumn{10}{|l|}{ TRICHOPTERA } \\
\hline Aoteapsyche spp. & + & + & + & + & + & + & + & + & + \\
\hline Plectrocnemia maclachlani & + & + & + & & & & & & \\
\hline Hydrobiosella mixta & + & + & + & + & & & & & \\
\hline Hydrobiosis styx & + & & & + & & & & & \\
\hline Hydrobiosis clavigera & & & & + & + & & & + & \\
\hline Hydrobiosis parumbripennis & + & + & + & + & + & + & + & + & + \\
\hline Hydrobiosis frater & & & + & & & & & & \\
\hline Hydrobiosis spp. & + & + & + & + & + & & + & + & + \\
\hline Psilochorema bidens & + & + & + & + & & & + & + & \\
\hline Psilochorema nemorale & + & & + & + & + & + & + & + & + \\
\hline Psilochorema sp. & + & + & & & & & & & \\
\hline Neurochorema confusum & & & & & + & + & & + & \\
\hline Costachorema peninsulae & + & + & + & + & & & & & \\
\hline Edpercivalia banksiensis & + & & + & + & & & & & \\
\hline Tiphobiosis sp. A & & + & & + & & & & & \\
\hline Oxyethira albiceps & & & & & + & + & + & + & + \\
\hline Pycnocentria evecta & + & + & + & + & + & + & + & + & + \\
\hline Pycnocentria sylvestris & + & + & + & + & & & & & \\
\hline
\end{tabular}




\begin{tabular}{|c|c|c|c|c|c|c|c|c|c|}
\hline & $\mathrm{FH}$ & $\mathrm{FM}$ & FL & $\mathrm{MH}$ & MM & ML & $\mathrm{AH}$ & $\mathrm{AM}$ & $\mathrm{AL}$ \\
\hline Pycnocentrodes sp. & & + & + & & + & + & & + & + \\
\hline Beraeoptera roria & & & + & + & + & & & & \\
\hline Olinga feredayi & + & + & + & + & + & + & + & + & + \\
\hline Hudsonema aliena & & + & + & & + & & + & + & + \\
\hline Hudsonema amabilis & + & + & & + & & + & & & \\
\hline Helicopsyche sp. & + & + & + & + & + & + & + & + & + \\
\hline Philorheithrus agilis & + & + & + & + & + & & + & & + \\
\hline ANNELIDA & + & + & + & + & + & + & + & + & + \\
\hline $\begin{array}{l}\text { PLATYHELMINTHES } \\
\text { MOLLUSCA }\end{array}$ & + & + & + & + & + & & & + & \\
\hline Potamopyrgus antipodarum & + & + & + & + & + & + & + & + & + \\
\hline Physa spp. & & & & & + & & + & & + \\
\hline $\begin{array}{l}\text { Lymnaea } \\
\text { CRUSTACEA }\end{array}$ & + & + & & & + & + & + & & + \\
\hline Amphipoda & & & + & & & & & & \\
\hline Ostracoda & + & + & & & & + & & & + \\
\hline Atyria & & & & & & & & & + \\
\hline COLLEMBOLA & + & & & & & & + & & \\
\hline
\end{tabular}


